\title{
The effect of enriched environment and handling on the learning of a visual discrimination task'
}

CHRISTINE RINCK, University of Missouri and Veterans Administration Hospital, Kansas City, Mo.

To assess the effect of environment and handling on the learning of a visual discrimination task, four groups of rats were raised under the following conditions: enriched cnvironment home cage with or without handling and sterile environment home cage with or without handling. Significant differences were obtained on the visual discrimination task as well as on emotionality and exploratory tests between handled and unhandled groups regardless of environment.

Hebb (1949) saw the basis of the excessive exploratory activity, immature emotional responses and deficiences of responses to pain in Scottish terriers in their need for a long period of "perceptual learning" for the organization of the central nervous system. Fuller (1967) has hypothesized in his emergency-stress model that animals reared in isolation fail to habituate to multitudinous stimuli and therefore would have more difficulty in learning a complex discrimination. In a visual black/white discrimination task puppies who had been isolated performed more poorly than those who had been reared as pets. Although the differences between the two groups was not significant, Fuller felt that on a more complex discrimination, the differences would be higher.

Fuller (1967) also found that puppies whose isolation was broken only once a week played with a ball and towel significantly less than those whose isolation was broken four times a week. However, there was no significant difference in the amount of locomotion on a closed field test between the groups. Weininger (1956) and Denenberg et al (1962) found that handled rats did show increased locomotion on an open field test.

The finding that handled rats are less emotional than unhandled rats appears to be almost a universal finding (Eels, 1961; Ades, 1966; DuPres, 1964; Weininger, 1956; Bell, 1964).

The purpose of this experiment was to determine the effect handling and environment had on the emotional and exploratory behavior in rats and how this correlated with the performance on a visual discrimination.

Subjects.

\section{METHOD}

Eight male albino rats of the Sprague-Dawley strain which were shipped from Simonsen Laboratory, Gilroy, California, at $\mathbf{3 0}$ days of age were used for this study.

Apparatus.

The Thompson-Bryant Box (1955) used in the visual discrimination portion of this experiment consists of a startbox, runway, two entryways and a goalbox. There is a guillotine door between the startbox and runway.

Procedure.

The rats were divided into four groups of two rats each and individually caged as follows: Group $A$ was housed in the "enriched environment" cages (which contained a yellow rattle; painted toy turtle, painted airplane; and mirror with bell attached to the end of the mirror) and received no handling; Group B was housed in the "enriched environment" cages and received handling daily; Group $C$ was housed in normal cages and received no handling prior to experimentation; and Group D was housed in normal cages and received handling daily prior to experimentation. "Handled" animals were handled by the experimenter for several minutes daily prior to experimentation.

Forced Exploratory Test: At the end of 60 days a "forced exploratory test" was performed. This consisted in placing a staple remover into the home cage and observing the behavior emitted. Specific measures were taken to determine the amount of time sniffing the staple remover and the amount of time handling it.

Closed Field Study: At the end of 60 days each animal was placed separately in a cylinder which had 4 in. squares marked on the bottom. Independent observers followed the path taken by each rat during a $3 \mathrm{~min}$ period and the number of squares entered by the rat was calculated.

Emotionality Test: At the end of 60 days a King Emotionality Test $(1958)^{2}$ was performed. This consisted of the following measures: (a) putting a pencil to the nose of the rat and measuring his reaction; (b) tapping the rat 24 times on the back (alternating six times each side); (c) capturing and handling the rat to determine his reactions (vocalization, defecation and movement).

Visual Discrimination Learning: Ss were pretrained in a Thompson-Bryant (1955) box to run to the goalbox in order to avoid shock and to knock over grey stimulus cards which blocked the goalbox entryways. The Ss were then trained at the rate of 25 trials a day on a discrimination of a horizontal/vertical pattern until a criterion of 18 out of 20 consecutive trials had been met. The stimuli doors were alternated according to a Fellows (1967) series. Training was then initiated on a pattern discrimination which was tilted $45 \mathrm{deg}$ to the right or left until a criterion of 18 out of 20 trials correct was obtained. The third discrimination which was the reverse of the second discrimination was undertaken until a criterion of 18 out of 20 correct trials was met or until 300 trials had elapsed (whichever came first). RESULTS ${ }^{3}$

Forced Exploratory Test: The handled group sniffed and handled the object significantly more than the unhandled group $(p<.001 \mathrm{~F}=91.2, \mathrm{df}=1,4)$. They handled and sniffed the staple remover a mean of $157 \mathrm{sec}$ as opposed to a mean of $61 \mathrm{sec}$ for the unhandled group. The handled group also handled the object significantly more $(F=15.7$, df $=1,4 p<.05)$. One rat in the unhandled group failed to handle the object at all. (See Table 1)

Closed Field Study: The handled group entered a mean of $24 \mathrm{sq}$ while the unhandled group entered a mean of $14 \mathrm{sq}$. This difference, however, was not significant at the .05 level (See Table 1).

Emotionality Test: The unhandled group exhibited significantly more emotion than the handled group $(F=16.51$, df $=1,4$, $p<.025)$. The unhandled group had much higher scores on capture and handling measures. (See Table 2)

Visual Discrimination Task: There were no significant differences between handled nor unhandled groups on the first discrimination task (See Table 3). The handled group reached criterion in a mean of 42 trials as opposed to 53 trials to criterion for the unhandled group. However, there was a significant difference at the .05 level for trials to criterion ( $F=9.69$, $\mathrm{df}=1,4$ ) and errors to criterion $(F=14.65$, $\mathrm{df}=1,4)$ on the second

Table 1 Exploratory Studies: Results

\begin{tabular}{cccc}
\multicolumn{2}{c}{ HANDLED } & & \multicolumn{2}{c}{ UNHANDLED } \\
\cline { 4 - 5 } Sterile & Enriched & Sterile & Enriched \\
$\begin{array}{c}\text { Environ- } \\
\text { ment }\end{array}$ & $\begin{array}{c}\text { Environ- } \\
\text { ment }\end{array}$ & $\begin{array}{c}\text { Environ- } \\
\text { ment }\end{array}$ & $\begin{array}{c}\text { Environ- } \\
\text { ment }\end{array}$ \\
\hline
\end{tabular}

Forced Exploratory Test

Mean No. Sec

Sniffed and

Handled Object

$$
162
$$

153

62

Handled Object

$$
153
$$

104

21

\section{Closed Field Exploration}

Mean No. of

Squares Explored

35

15

8

21

$N=2$ subjects per group 
Table 2

Emotionality Test Results

\begin{tabular}{cccc}
\multicolumn{2}{c}{ HANDLED } & & \multicolumn{2}{c}{ UNHANDLED } \\
\cline { 1 - 2 } $\begin{array}{c}\text { Sterile } \\
\text { Environ- } \\
\text { ment }\end{array}$ & $\begin{array}{c}\text { Enriched } \\
\text { Environ- } \\
\text { ment }\end{array}$ & $\begin{array}{c}\text { Sterile } \\
\text { Environ- } \\
\text { ment }\end{array}$ & $\begin{array}{c}\text { Enriched } \\
\text { Environ- } \\
\text { ment }\end{array}$ \\
\hline
\end{tabular}

\begin{tabular}{|c|c|c|c|c|}
\hline $\begin{array}{l}\text { Reaction to Pencil } \\
\text { Presentation }\end{array}$ & 1.5 & 2 & 1 & 2 \\
\hline $\begin{array}{l}\text { Reaction to Pencil } \\
\text { Tapping }\end{array}$ & 1.3 & 1.5 & 1.3 & 2.5 \\
\hline $\begin{array}{l}\text { Reaction to Capture } \\
\text { and Handling }\end{array}$ & 1.5 & 2.5 & 7.3 & 7.0 \\
\hline $\begin{array}{l}\text { Vocalization and } \\
\text { Urination during } \\
\text { Handling }\end{array}$ & 0 & 0 & 6 & 4.3 \\
\hline $\begin{array}{l}\text { Total Emotionality } \\
\text { Score }\end{array}$ & 4.3 & 6 & 15.5 & 16.3 \\
\hline
\end{tabular}

$N=2$ subjects per group

discrimination task. The handled group had a mean of 73 trials to criterion while the unhandled group had a mean of 116 . The handled group had a mean of only 32 errors to criterion and the unhandled group a mean of 53. On the third discrimination the handled rats had significantly less trials to criterion $(F=10.1, \mathrm{df}=$

Table 3

Mean Visual Discrimination Task Results

\begin{tabular}{|c|c|c|c|}
\hline \multicolumn{2}{|c|}{ HANDLED } & \multicolumn{2}{|c|}{ UNHANDLED } \\
\hline Sterile & Enriched & Sterile & Enriched \\
\hline $\begin{array}{c}\text { Environ- } \\
\text { ment }\end{array}$ & $\begin{array}{c}\text { Environ- } \\
\text { ment }\end{array}$ & $\begin{array}{c}\text { Environ- } \\
\text { ment }\end{array}$ & $\begin{array}{c}\text { Environ- } \\
\text { ment }\end{array}$ \\
\hline
\end{tabular}

First Discrimination Task

\begin{tabular}{lrrrr} 
Trials to Criterion & 40 & 44 & 68 & 53 \\
Errors to Criterion & 19 & 18 & 27 & 24 \\
Second Discrimination Task & & & & \\
\hline Trials to Criterion & 59 & 87 & 95 & 132 \\
Errors to Criterion & 25 & 39 & 58 & 48 \\
Third Discrimination Task & & & & \\
\hline Trials to Criterion & 132 & 171 & $252+$ & 231 \\
Errors to Criterion & 81 & 100 & $149+$ & 144 \\
\hline
\end{tabular}

$N=2$ subjects per group

+ One rat did not reach criterion after 300 trials
$1,4 ; p<.05)$. The mean trials to criterion were 152 for the handled group and 244 for the unhandled group. The mean errors to criterion for the handled group were 90 while those of the unhandled group was 148 . This was just under significance at the .05 level.

\section{DISCUSSION}

In order to learn a visual discrimination task the animal must bring certain elements into the situation: his emotional behavior, his perceptual ability and his ability to attend to the relevant cues of the situation. It would appear from this study that the rats whose environment was such as to give early perceptual stimulation did not perform significantly better on the discrimination. However, those who were handled showed less emotionality under situations similar to those of the learning situation and explored and manipulated a novel object more when it was placed in their cage. These rats performed significantly better on the complex discriminations.

It would appear that this experiment confirmed the emergency-stress model of Fuller (1967) and that it failed to confirm the "perceptual learning" theory of Hebb (1949).

$$
\text { REFERENCES }
$$

ADES, R. Frequency of stimulation during early life and subsequent emotionality in the rat. Psychological Reports, 1966, 18, 695-701.

BELL, R. W. Emotionality after mild chronic stress as a function of infantile handling. Psycholugical Reports, 1966, 14, 657-658.

DENENBERG, V. H., MORTON, J. R., KLINE, N. J. \& GROTTA, L. J. Effects of duration of infantile stimulation upon emotionality. Canadian Journal of Psychology, 1962, 16.

EELS, J. F. Inconsistency of early handling and its effect upon emotionality in the rat. Journal of Comparative \& Physiological Psychology, 1961, 54, 690-693.

FELLOWS, B. J. Change stimulus sequences for discrimination tasks. Psychological Bulletin, 1967, 67, 87-92.

FULLER, J. L. Experiential deprivation and later behavior. Science, 1956, $158,1645-1652$.

HEBB, D. O. The organization of behavior. New York: Wiley, 1949.

KING, F. A. Effects of septal and amygdaloid lesions on emotional behavior and conditioned avoidance responses in the rat. Joumal of Nervous \& Mental Disease, 1958, 126, 57-63.

THOMPSON, R., \& BRYANT, H. Memory as affected by activity of the relevant receptor. Psychological Reports, 1955, 1, 393-400.

WEININGER, 0 . The effects of early experience on behavior and growth characteristics. Journal of Comparative \& Physiological Psychology, 1956, $49,1-9$.

\section{NOTES}

1. This study was supported in part by 8200 (Research) funds from the Veterans Administration and in part by Grant USPH-NB-07445-02 from the Public Health Service to Dr. Charles L. Sheridan.

2. The author wishes to thank Dr. Patricia Meyer for sending her a copy of the emotionality scale.

3. All ps in the 2 by 2 factorial ANOVA based on Environment and the Handling by Environment interaction were $>.05$. 